\title{
THE RELEVANCE OF LINKING FAVOURABLE BUSINESS ENVIRONMENTS WITH EMBEDDEDNESS SMES IN RURAL AREAS OF THE GORIŠKA REGION, SLOVENIA
}

\author{
Irma Potočnik-Slavič ${ }^{1}$
}

Received 30 April 2011; Accepted 23 September 2011

\begin{abstract}
Contemporary Slovene rural areas as multifunctional localities with heterogeneous and mosaic structures and, exposed to enormous restructuring, are trapped between traditional processes and structures on one side and modern development processes on the other. Goriška (predominately a rural area) is part of a strongly integrated cross-border region with a very diverse geographical structure, huge historical, cultural and natural heritage and a significant share of LFAs with increasing levels of inter-regional disparities. This paper focuses on networking of SMEs in these Slovene rural areas. The results confirm the complex nature of the relationships between favourable business environments (built-up and supportive business milieu) and processes of embeddedness and international integration.
\end{abstract}

Key words: rural areas, rural business, SME, business zone, favourable business environment, embeddedness, globalization, Goriška, Slovenia.

Izvleček: Sodobno slovensko podeželje kot večfunkcijski prostor z izjemno heterogeno in mozaično strukturo doživlja velike spremembe, saj je ujeto med kolesje tradicionalnih procesov in struktur ter sodobnih razvojnih procesov. Goriška statistična regija (»pretežno podeželsko območje«) ima kot del močno povezanega čezmejnega območja zelo raznoliko geografsko strukturo, bogato zgodovinsko, naravno in kulturno dediščino, omejene, a specifične pogoje za kmetovanje in se sooča s pomembnimi medregionalnimi razlikami. Članek se osredotoča na vzpostavitev mrežnih povezav majhnih in srednjevelikih podjetij na podeželju. Rezultati potrjujejo zapleten sistem odnosov med podjetniškim okoljem (grajenim in spodbudnim) in vpetostjo $v$ lokalno okolje na eni in vključenostjo $v$ mednarodne tokove na drugi strani.

Ključne besede: podeželje, podeželske podjetije, mala in srednje velika podjetja, poslovna cona, ugodne poslovne okolje, globalizacija, Goriška, Slovenija

\footnotetext{
1 Irma Potočnik Slavič, PhD., University of Ljubljana, Faculty of Arts, Department of Geography, Aškerčeva 2 , 1000 Ljubljana, e-mail: irma.potocnik@ff.uni-lj.si
} 


\section{Introduction}

In the era of globalization, small firms located in rural areas especially, are extremely fragile (Klemenčič, Lampič, Potočnik Slavič 2008). The reconstitution of rural spaces under globalization introduces into rural localities new networks of global interconnectivity, which become threaded through and entangled with existing local assemblages, sometimes acting in concert and sometimes pulling local actants in conflicting directions. The networks, flows and actors introduced by globalization processes fuse and combine with extant local entities to produce new hybrid formations. In this way, places in the emergent global countryside retain their local distinctiveness, but they are also different to how they were before" (Woods 2007: $499-500)$.

As there is a distinctive body of literature on globalization with a prevailing focus on urban areas (for example Hogan 2004 etc.), the DERREG project ${ }^{*}$ is addressing the globalization processes in rural business development. If we generalize, the firms in rural areas usually decide on one of the following options: (1) they stay enrooted in local milieu if this is permitted by the nature of their business and economy of scope, or (2) they combine a certain stage of embeddedness with some connections to outer wider systems (often recognized as glocalization; Klemenčič 2005, Massey 2005) or (3) they are completely integrated into international networks. In practice this appears far more complex: as the empirical examples indicate, both processes (globalisedness, Dubois 2010) are in fact parallel and multidimensionally interwoven.

Young (2010) gives direction to this hypothesis in that one cannot state that more locally oriented firms (in terms of sales, purchase, business co-operation, financing) are more embedded in the local environment; just as it cannot be confirmed that strongly internationalized (globalized) firms in rural areas tend to be less embedded in local milieu. This hypothesis then is tested by surveying two drives that essentially create local/regional/international business environments, i.e. the development of built-up facilities and the forms of supportive business climate. If the both mentioned drivers are set-up and correlating properly, they should create favourable circumstances in which firms could flourish and network on various levels.

Using small-scale analysis, this paper explores: what kind of business environment is favourable for firms in rural areas to develop relevant networks in local/regional/international milieu. The case study area chosen is the predominantly rural Goriška region, (this is based on the OECD methodology whereby all Slovenian NUTS 3 regions are defined as "rural" albeit that within this framework that while Slovenia seems to be quite uniform (9 regions are declared as "predominantly rural", 3 as "significantly rural"), geographically the country is enormously diverse as it is situated at the crossroads of important European geographic macro regions (Alps, Pannonian basin, Mediterranean basin, Dinaric-Karst region and near to the Balkans) with various socioeconomic implications.

\section{Materials and Methods}

Favourable business environments are usually constructed by interrelationships between (1) suitable built-up environments and (2) networking of various actors and institutions at different levels constructing a supportive business climate.

(1) In structurally weak areas business zones (BZ) were introduced as the last measure for economic revitalization. With less severe regulations (lower price of land, lower taxes, subsidies for salaries) BZ should attract investors and increase attractiveness of a locality's working environment. Although they have quite a number of advocates, they are usually in the centre of critical discourses regarding their real advantages. BZs as described above have been established in Slovenia from the mid 1990s with numerous BZs having flourished since this time (Potočnik Slavič 2010a).

The OECD defines BZs as parts of land, developed and divided in business units according to the plan; as well as basic buildings they also offer infrastructure (traffic, electricity, water supply, sewage system, telecommunications). They are designed to house lease enterprises and are therefore an instrument of regional economic policy and a spatial planning tool. Primarily, they are focused on production, construction, logistic and service 
businesses; they can also support wholesale and retail (but not as dominant activities, operating more as a support for the employees). BZs, with local community support, help attract new investments on a national and international basis. This highly dynamic and relevant spatial phenomenon was particularly observed in Slovenia during the period of 2006 to 2008.

(2) Blakely and Bradshaw (2002) define three waves of creating a stimulating business climate (or an economic development strategy). The first wave is usually considered to be business attraction ("an attractive package for firms": tax inducements, financing packages, promises of lower overall costs etc.). Afterwards, a broader set of strategies (second wave) retain a component of business attraction, but add strategies to retain and expand existing businesses and incubate new enterprises (expansion loans and grants to firms with new markets that could expand locally or globally, with a special focus also on SMEs). The third wave is still emerging (as outlined in the new concept in Table 1) and rather than dealing with firms one by one, it is focused on using regional resources to support the growth of specified clusters. Clearly evident here is an attempt to link technology, human resources and capital in such a way as to give networked firms a global competitive advantage. Van der Ploeg and Marsden (2008) refer to this as unfolding (rural) webs.

\begin{tabular}{|l|l|l|}
\hline Element & Old concept & New concept \\
\hline Locality & $\begin{array}{l}\text { Physical location (near natural } \\
\text { resources, transportation, markets) } \\
\text { enhances economic opportunities. }\end{array}$ & $\begin{array}{l}\text { A quality environment and strong } \\
\text { community capacity empower the } \\
\text { strengths of locality. }\end{array}$ \\
\hline $\begin{array}{l}\text { Entrepreneurship and } \\
\text { economic base }\end{array}$ & $\begin{array}{l}\text { Export base industries and firms } \\
\text { create jobs and stimulate increased } \\
\text { local economy. }\end{array}$ & $\begin{array}{l}\text { Clusters of competitive companies } \\
\text { linked in a regional network of } \\
\text { various types of firms, create } \\
\text { economic growth and income. }\end{array}$ \\
\hline $\begin{array}{l}\text { Employment } \\
\text { resources }\end{array}$ & $\begin{array}{l}\text { More firms are focused on higher } \\
\text { amount of employees, although low } \\
\text { paid. }\end{array}$ & $\begin{array}{l}\text { Comprehensive skills development } \\
\text { and technological innovation lead } \\
\text { to quality jobs and better wages. }\end{array}$ \\
\hline Community sources & $\begin{array}{l}\text { Single-purpose organizations can } \\
\text { enhance economic opportunities in } \\
\text { the community. }\end{array}$ & $\begin{array}{l}\text { Collaborative partnerships of } \\
\text { various community groups are } \\
\text { needed to establish a broad } \\
\text { foundation for competitive firms. }\end{array}$ \\
\hline
\end{tabular}

Tab 1. Old and New Concept of Local Economic Development. Source: Adapted upon Blakely and Bradshaw (2002: 67).

In developing the indicators for the embeddedness of firms, a strong focus was placed on networks and partnerships (the predominant orientation of the above mentioned "new concept"). The notions of 'embeddedness' and 'globalisation' are often related to a specific territorial scale, respectively local and international. By definition embeddedness means to be anchored in a larger structure (Johannisson et al. 2002) and according to Granovetter $(1985,1992)$ also refers to the fact that 'economic action is affected by actor's dyadic relationships and by the structure of the overall network of relations' (Granovetter 1992 p. 33). Some argue that embeddedness stands for the social responsibility of firms (for example by providing grant schemes, financing events, investing in public infrastructure etc.). The DERREG hypothesis (Dubois 2010) is that both processes are in fact parallel: they represent two different ways of 'sensing' the dynamics of a firm's business network. Our assumption is that 'globalisedness', i.e. the degree of globalisation of a firm, and embeddedness, are feeding each other, that is to say that a SME that is highly globalised is, to some extent, well embedded in its local setting. Indeed, as Johanson and Mattsson (1988; cited in Dubois 2010) suggest, "as the firm internationalises, the number and strength of the relationships between different parts of the business network increases", implying that regional linkages might well be reinforced. This is in line with Taylor's assumption (2004) that "despite economic globalization, local business linkages remain as important as ever. While there are transnational processes many of which are world-wide in scope, they operate alongside many other processes that are non-global in scope". 
This intertwining between the globalisation and embeddedness aspects of business networks was further emphasised by Johannisson and his colleagues: "To our mind it is difficult to provide a thorough understanding of the global networking of the individual firm (egocentric networking') without considering the overall networking ('sociocentric networking') between businesses in the context concerned" (Johannisson et al., 2002 p. 43). As a matter of consequence, the globalisedness and embeddedness character of the business networks can be addressed by integrating the territorial and social dimensions of inter-organisational linkages.

The results of this paper are based on the use of two methodological approaches:

(1) The DERREG methodology is focused on addressing globalization processes in rural business development. After scoping the relevant literature, the profile of business structures in the case study region, based on explicit statistical data at a NUTS 3 level, was compiled. This was supplemented with the selection of a representative sample of firms (20) that were included in an electronic survey which was, amongst others, focused on how rural businesses derive strength from being part of a small, supportive business community as well as other aspects of their local business environment (such as close links to local institutions and agencies). In-depth explanations were provided by face to face structured interviews (8) with those firm managers willing to co-operate. The contextual analysis for the wider business environment was supplemented by interviews with actors responsible for business development (6).

(2) An up-grading our current research on the built-up business environment (through existing BZs, 57 were surveyed in total; Potočnik Slavič 2010a) in Slovenia, extensive fieldwork for each BZ was conducted which included a three-folded research approach: (a) all municipality professionals were included (research of BZ planning and development data, 57 interviews); (b) entrepreneurs (questionnaire on motives for firm set-up in the owners); (c) local population (questions on contacts to and future development of BZ; 879 correspondents aged over 18). The set-up and development of several BZs in the Goriška region (a network model connecting BZs of Kobarid, Podljubinj, Tolmin, Vipava, Gojače, Miren-Orehovlje, Šempeter pri Gorici, Batuje, Štaloni, Godovič) was surveyed and compared with other parts of Slovenia.

\section{Results}

\subsection{The Business Profile of the Goriška Region}

The Goriška region (2325 km²; $11.5 \%$ of national territory; SURS 2009) extends over the western part of Slovenia (bordering Italy) and is situated at a geographical crossroads of regions, i. e. alpine, pre-alpine, karst-dinaric and sub-Mediterranean resulting in a mosaic landscape structure. The valleys of rivers Soča and Vipava function as its communication, transport, demographic and economic axis. In general, the Goriška region is characterized by low population density (51 inhabitants $/ \mathrm{km}^{2}$ ), a total population of 120,329 in 2007; SURS 2008) and dispersed settlement; with Nova Gorica and its hinterland being the only agglomeration area. Negative demographic trends are especially evident in hilly and mountainous areas where an ageing population has been an important issue for decades.

The Goriška region is an important part of the Gorizia transborder region, a typical example of a consolidated historical region which has only been divided by frontier since WW2. Towards the end of the 1960s, after the abolition of entry visas and the stabilizing of political relations between Italy and Yugoslavia, this border became known as one of the most "open" boundaries in Central Europe. Since EU integration in 2004 this region has become a strongly integrated cross-border area, a situation that is very important for business development.

Due to the polycentric development since the 1970s, some sub-regional centres emerged (for example Ajdovščina, Idrija, Cerkno, Vipava, Tolmin, Bovec), with other areas undergoing very rapid development, specialization and broadening of their economic base widening (wine- and fruit-growing, together with tourism development in the Goriška Brda hilly region; Potočnik Slavič 2010b), whilst others, mostly remote, are dependent hugely on environmental capital (Upper Soča Valley, being also part of the protected areas of Triglav National Park). In the late 
1970s also the Goriška region got a special status approved by the state for gambling and betting activities (there is a casino centre in Nova Gorica and also small gambling units dispersed in the Slovene-Italian border region).

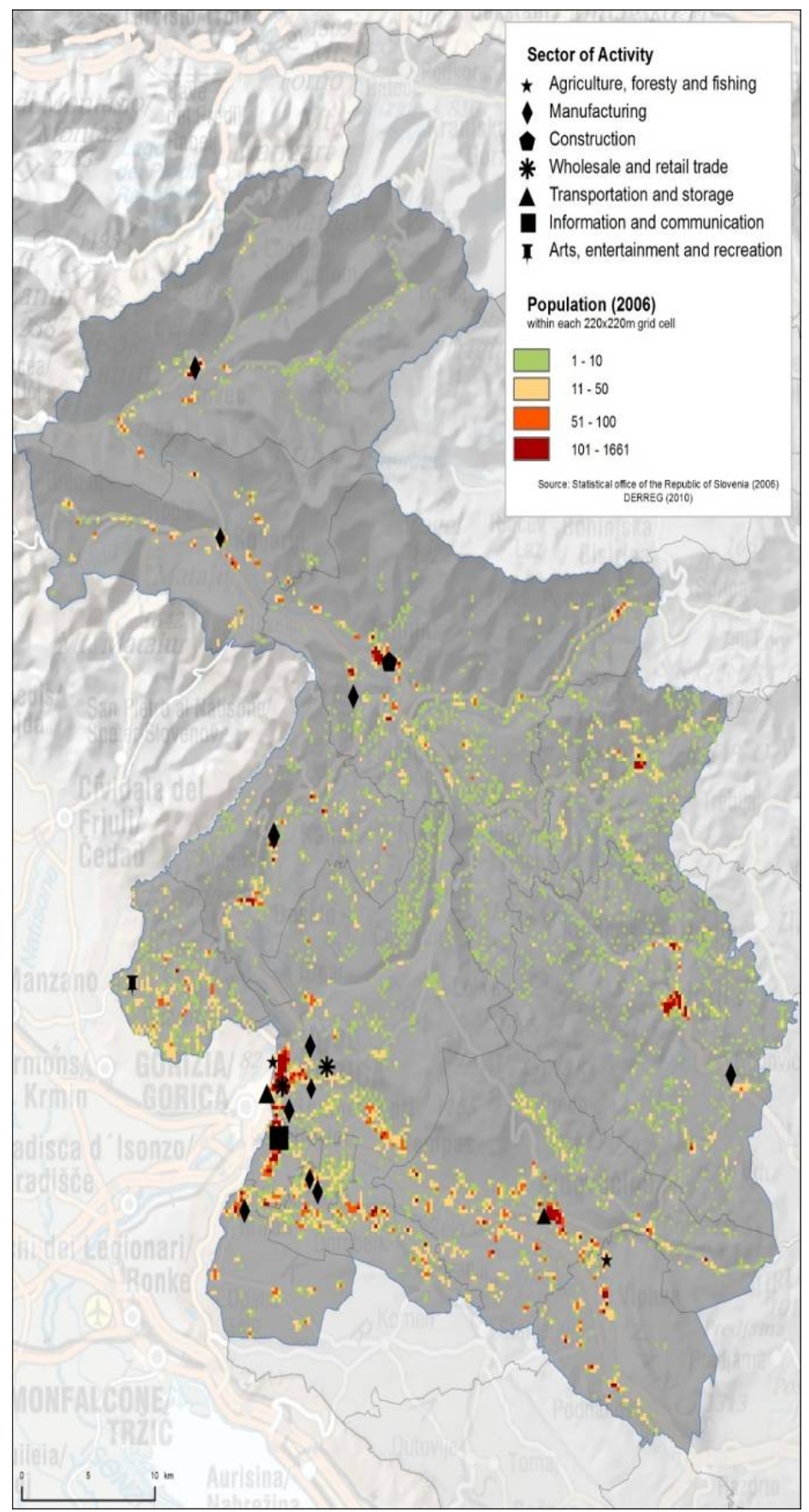

Fig 1. Goriška region - Population Density and Spatial Distribution of Firms Included in Electronic Survey.

Since Slovenia gained independence in 1991, the Goriška region has been one of the most dynamic and leading Slovenian regions (usually ranked second or third behind the central part with the capital of Ljubljana and littoral region) with GDP $19.800 €$ per inhabitant (SURS 2009). The growth of various businesses could in Slovenian terms described as "high growth" mostly due to open borders, traditionally good connection to Italy, a beneficial business environment, relatively fast spatial planning revision, good entrepreneurial examples from Italy and the set-up of cross-border economy projects etc. Again, the inter-regional heterogeneity has to be emphasised: Nova Gorica and its hinterland and partly Vipava Valley have displayed very dynamic economic development. More remote areas sustain two trends however: out-migration of (younger) locals, and in-migration of retired people (returnees) and extra-locals searching for special amenities in the unique milieu. 
The population census 2002 for the Goriška region showed 50.488 persons in employment: $3,9 \%$ in agriculture, $41,3 \%$ in manufacturing, $48 \%$ in services, and $6,8 \%$ as a category "unknown".

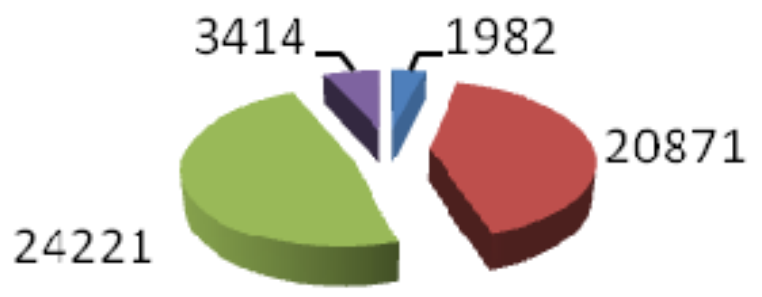

\section{Agriculture $\square$ Manufacturing $\square$ Services $\square$ Unknown}

Fig 2. The Structure of Persons in Employment (Goriška region, 2002). Source: Population Census, SURS, 2002.

Data for 2008 (AJPES) indicated that in the Goriška region:

- 2548 commercial companies had 28.311 employees,

- 273 people were employed in 19 co-operatives,

- 5185 registered solo enterprises were registered with 3327 employees,

- associations (1272) gave employment to 102 persons,

- private law employed 217 people (281 units),

- public law (education, culture etc.) employed 5827 people in 102 units.

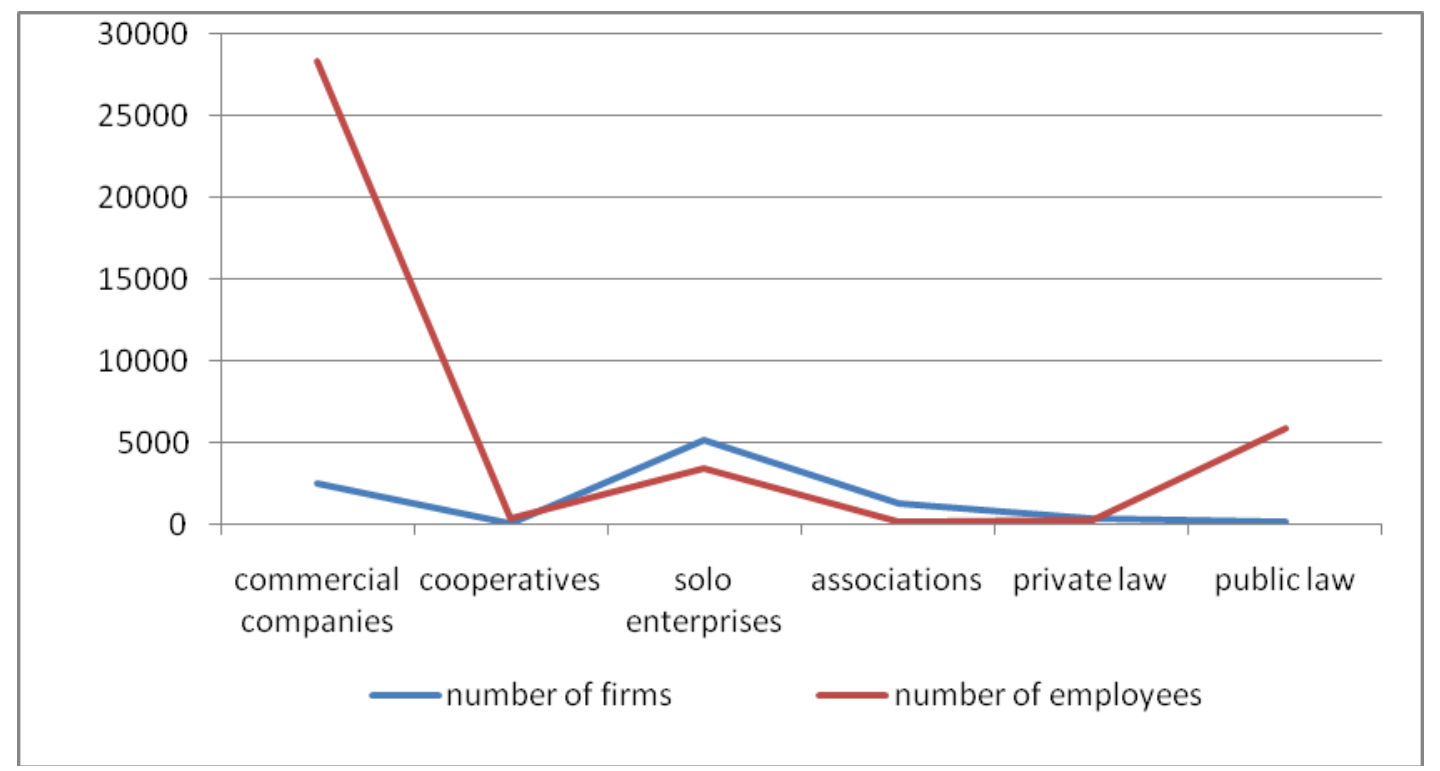

Fig 3. The Structure of Firms (number of firms and employees) in Goriška region. Source: AJPES 2008, 2009.

For commercial companies in the Goriška region the breakdown of companies are (AJPES, 2008 and 2009):

- $\quad 61,3 \%$ are classified as micro-firms (1-9 employees),

- $16 \%$ rank as small and medium-sized firms (10-49 employees),

- $12,9 \%$ are larger firms (50 to 250 employees), and

- $9,8 \%$ are characterised as big firms (over 250 employees, banks, insurance companies etc.). 


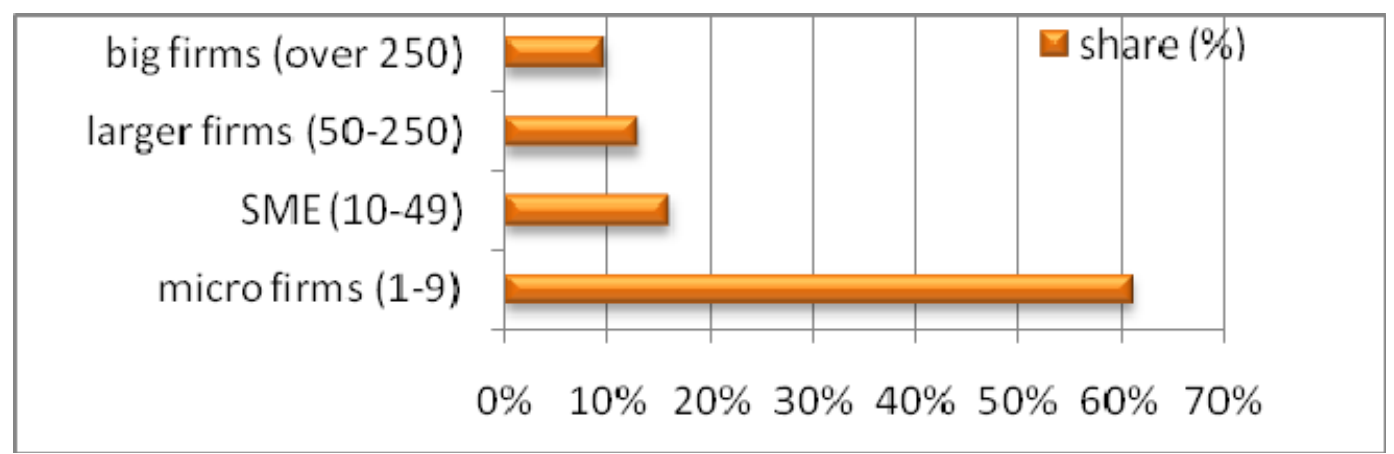

Fig 4. The Size of Commercial Companies in the Goriška region. Source: AJPES 2008, 2009.

The largest numbers of commercial companies are connected to the manufacturing sector. All other economic activities with bigger numbers of companies (wholesale and retail, repair of motor vehicles and motorcycles, construction, professional, scientific and technical activities, other service activities, accommodation and food-service activities, agriculture) have a rather small-size structure with micro firms prevailing.

Co-operatives (19 with together 273 employees; AJPES 2008, 2009) comprise of the following structure:

the majority belong to micro firms,

co-operatives in Dobrovo (wine), Idrija (meat and dairy products) and Tolmin (dairy products) have 50 to 150 employees,

- the co-operative in Vipava (various agro-products) ranks amongst the biggest firms.

There have been 5,185 solo-firms with 3,327 employees in 2008 (AJPES). Solo firms are dominant in the following economic sectors: manufacturing, construction, wholesale and retail, transportation and storage, education, accommodation and food service activities. Public law firms (mostly dealing with education, public administration, health and social services etc.) consisted of 254 units with 5,827 employees. Private law firms (dealing with finance and insurance, education and arts) registered 217 employees in 281 units. Various associations $(1,272)$ had also been registered; in general they are based on voluntary work and employ only 102 persons (AJPES 2008, 2009).

The most dynamic sectors in the period 1991-2008 were (SURS 2009):

- the sector of public administration, social security, education, health and social work etc. (growth index 192);

financial intermediation, real estate, renting and business activities (growth index 178), construction (170), mining and quarrying, electricity, gas and water supply (growth index 162),

agriculture, hunting, forestry had kept almost the same value throughout the whole period.

\subsection{Networking of Rural Businesses: Evidence of Interconnectivity between Local Engagement and International Integration}

As stated above, there is a shortage of SMEs in the Goriška region. Using the database, provided by the Chamber of Commerce and Industry, we enlisted approximately 100 firms that would address the objectives of our research (119 firms were contacted by telephone). Out of 20 responses, only three companies were considered as "local" (based on SME Index of Globalization, provided by the OECD) with sales and purchases mostly taking place within the regional borders. $80 \%$ of responding companies were partly or strongly involved in international trade: 9 firms belong to the category "internationalized interfaces" and 7 to the category of "globalized" firms. The data confirm that most of the firm's activities are taking place outside the regional framework. Even the surveyed firms that have a strong international profile perform only a modest share of their total transaction outside the European continent. 


\begin{tabular}{|c|c|c|c|c|c|c|c|}
\hline & \multicolumn{6}{|c|}{ SALE S } \\
\hline & & Low & $\begin{array}{l}\text { Medium } \\
\text { Low }\end{array}$ & Medium & $\begin{array}{l}\text { Medium } \\
\text { High }\end{array}$ & High & Total \\
\hline \multirow{6}{*}{ 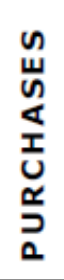 } & Low & 1 & & & & & 1 \\
\hline & Medium Low & & & 1 & & 1 & 2 \\
\hline & Medium & & & 1 & & 3 & 5 \\
\hline & Medium High & & & & & 1 & 3 \\
\hline & High & & & 4 & & 5 & 9 \\
\hline & Total & 1 & 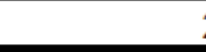 & 6 & & 10 & 20 \\
\hline
\end{tabular}

Source: DERREG, E-survey, 2010.

Tab 2. Typology of Surveyed Firms in the Goriška region According to their Transactional Space.

\begin{tabular}{|c|c|c|c|c|c|c|}
\hline $\begin{array}{l}\text { Firm } \\
\text { No. }\end{array}$ & Location & $\begin{array}{l}\text { Firm } \\
\text { start }\end{array}$ & $\begin{array}{l}\text { Firm } \\
\text { ownership }\end{array}$ & Branch $^{1}$ & $\begin{array}{l}\text { Firm } \\
\text { size }^{2}\end{array}$ & \begin{tabular}{|l|}
$\begin{array}{l}\text { Perceived } \\
\text { level of } \\
\text { global } \\
\text { integration }\end{array}$ \\
\end{tabular} \\
\hline SI01 & Nova Gorica & 1952 & National & $\begin{array}{l}\text { Transportation and } \\
\text { storage }\end{array}$ & Medium & Low \\
\hline SI02 & Čiginj/Tolmin & 1992 & Independent & Manufacturing & Medium & average high \\
\hline SI03 & Bovec & 1957 & Local/regional & Manufacturing & Medium & High \\
\hline SI04 & Nova Gorica & 1999 & Foreign & $\begin{array}{l}\text { Wholesale and retail } \\
\text { trade }\end{array}$ & Small & average high \\
\hline SI05 & Nova Gorica & 1990 & Independent & Manufacturing & Medium & Low \\
\hline SI06 & Neblo & 2004 & Local/regional & $\begin{array}{l}\text { Arts, entertainment } \\
\text { and recreation }\end{array}$ & Medium & average high \\
\hline SI07 & Vrhpolje & 1994 & Independent & $\begin{array}{l}\text { Agriculture, forestry } \\
\text { and fishing }\end{array}$ & Micro & average high \\
\hline SI08 & Kromberk & 1991 & Independent & Manufacturing & Small & average high \\
\hline SI09 & Podljubinj & 1991 & Independent & Construction & Small & Low \\
\hline SI10 & Nova Gorica & 1993 & Local/regional & $\begin{array}{ll}\begin{array}{l}\text { Agriculture, forestry } \\
\text { and fishing }\end{array} & \\
\end{array}$ & Micro & average low \\
\hline SI11 & $\begin{array}{|ll|}\text { Kanal } & \text { ob } \\
\text { Soči } & \end{array}$ & 1998 & Foreign & Manufacturing & Large & High \\
\hline SI12 & Ajdovščina & 2006 & Independent & $\begin{array}{l}\text { Transportation } \\
\text { storage }\end{array}$ & Small & High \\
\hline SI13 & Koba & 1995 & Local/regional & Manufacturing & Small & average low \\
\hline SI14 & $\begin{array}{l}\text { Šempeter- } \\
\text { Vitojba }\end{array}$ & 1987 & Independent & \begin{tabular}{|ll} 
Information and \\
communication
\end{tabular} & Medium & High \\
\hline SI15 & Orehovlje & 1992 & Independent & Manufacturing & Medium & average high \\
\hline SI16 & Kromberk & 1999 & Independent & $\begin{array}{l}\begin{array}{l}\text { Wholesale and retail } \\
\text { trade }\end{array} \\
\end{array}$ & Small & average high \\
\hline SI17 & $\mathrm{G}$ & 1992 & National & Manufacturing & Medium & High \\
\hline SI18 & Kromberk & 1989 & Independent & Manufacturing & Medium & High \\
\hline SI19 & Volčja Draga & 1989 & Local/regional & Manufacturing & Medium & High \\
\hline SI 20 & Volčja Draga & 1994 & Foreign & \begin{tabular}{|l} 
Manufacturing \\
\end{tabular} & Small & average high \\
\hline
\end{tabular}

Source: DERREG, E-survey, 2010.

Tab 3. Main Characteristics of Responding Firms.

The results obtained by the 20 respondents on "collaboration with other companies" indicate that surveyed SMEs have established stronger relational ties with other SMEs (the most evident on national level) than with large firms or multinational companies (on European level).

In the interviews, company managers were asked to assess the importance of their relationships with public agencies, trade associations, research institutions and business consultants - divided into four territorial classes (regional, national, European, world). The strongest link of surveyed SMEs was to the national and regional (usually a function of the branch office) trade associations. The National level was very important also for the support of public agencies, research institutes and business consultants. Financial support for the surveyed firms had been most frequently offered by regional (usually branch offices) and national banks, with funds provided by public support programmes also used (albeit this was 
more important at a national level). The following comments give a good indication of these relationships.

Interviewee SI13 (localised dairy): "Our firm has very good co-operation with local environment: with kindergarten, schools - especially lately, they regularly visit the museum; the firm is always "there". People know each other in the valley and are constantly checking the quality of products. They sell piece by piece and no huge quantities (i. e. dairy products). The firm cooperates strongly with local community. Locals find this firm as a part of local community: not just the old, but also the young generations. Also in the future, the firm would like to have a "bonding and bridging role" in the area, focus on high quality products, and consequently support economic cycle in the valley."

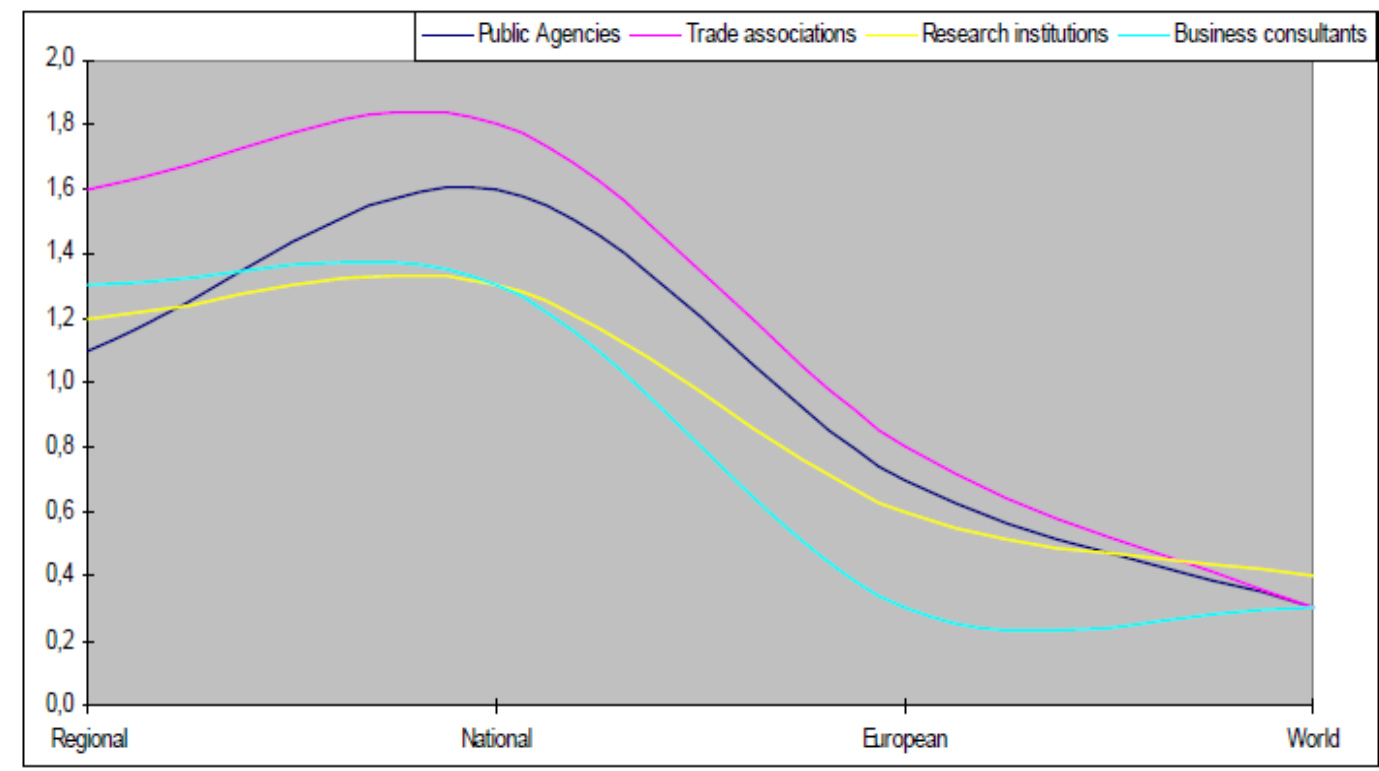

Source: DERREG, E-survey, 2010.

Fig 5. Average Responses Regarding Support from Institutional Actors Given by the Sample.

Interviewee SI02 (traditional manufacturing, medium high global integration): »Till the crisis, the firm was very generous in heterogeneous sponsorships in local environment: we sponsored elementary school and kindergarten renovation in Volče (village next to firm where a lot of workers live), also students and young people (usually family members of firm employees), local traditions, sports for employees."

Interviewee SI17 (large firm, research and production of complex air-heating systems, photovoltaic and solar systems, high level of global integration): "The owners of consortium are mostly middle aged persons that were on executive positions before the decay of socialist system. With managerial takeovers and other instruments they became owners of the firm that is a part of consortium that has national important role regarding employment. But this firm is also strongly attached to local environment, supporting students grant scheme, voluntary and professional local and regional organizations, events (sports, music etc.)."

\subsection{Supporting Business Milieu}

There are several fundamental national documents for entrepreneurship development: the National Development Programme of the Republic of Slovenia (2007-2013), the National Strategic Reference Framework, the Resolution on National Development Projects for the Period 2007-2023, and four Operational Programmes (Developmental potentials, Human Resources, Environmental and Transport Infrastructure, Territorial Cooperation). It is also important to emphasise the important role of the Resolution on National Development Projects as the first national document trying to follow the objectives of polycentric development at a project level (although the concept of polycentric development had been introduced in 1970s in the former Yugoslavia). This document seeks to leave behind the classical hierarchical and 
centrality model and aims at a model of decentralised networks of various development nodes mostly in urban regions, but with functional and gravitation connection to rural areas. It determines vision and goals of the country within common European regulations, policies and strategies, particularly the Lisbon Strategy. The main feature of this policy is its innerpolicentrality: there are several pools where some centres are being specialised on the basis of their local amenities and potentials. The Resolution contains 21 key projects (large and concentrated planning of investments with multisectorial results) whose implementation at the national and regional level will be focused on development initiatives and resources. Strategic documents are the basis for institutional and financial frameworks of entrepreneurship development on national, regional (important Scientific and Technology Parks in the Goriška region) and local levels.

For the Goriška region, regarding the regional policy landscape and relation between the actors, one could argue in two ways:

(1) there is no hierarchy model of institutions that represent the business support environment at regional level,

(2) the practical operation of business-support institutions on a regional level has not been harmonized.

As can be observed in Figure 8, there are several documents mentioned above that determine the operation of sectoral institutions at a national level (Ministry of Economy, Ministry of Agriculture, Forestry and Food, Office of Local Self-Government and Regional Policy, Slovene Enterprise Fund and Public Agency for Entrepreneurship and Foreign Investment). On the regional level the role of the following institutions are significant:

Chamber of Commerce and Industry (a regional branch for Northern Primorska region in Nova Gorica). This should be the main supporter of the business development, but in practice their activity is very limited (regarding finance and available human resources; Mihelj, 2011), since there is no obligatory membership for firms for the last few years. Firms are not interested to pay memberships as "they do not receive anything in exchange" (the general remark generated by in-depth firm interviews in 2010). This institution is supposed to have the most important role, but due to the lack of capacities mentioned their objective of supporting business development is very modest.

Chamber of Craft and Small Business (regional branch in Nova Gorica) has more "power" compared to the Regional Chamber of Commerce and Industry. At the moment, this institution has more financial and personnel capacities with numerous small firms included (membership is obligatory). They offer workshops, bigger business support structures, practical services (to prepare documents for firm registration; VEM Project), while also delivering craft permissions. The chamber is divided into special sections to address specific problems of firms. They also work as project partners (for example in LEADER initiatives), and are present not just in urban, but also in rural areas. They are also strong in business information dissemination (different calls in public media; Delo, 9. 6. 2009, p. 15) and represent the interests of their members at occasional meetings with politicians at national level, but with regional provenance.

The important role for business development is observable through the network of 4 regionaldevelopment agencies: RDA of Northern Primorska (seat at Vrtojba), ICRA (RDA for Idrija and Cerkno region), Business Support Centre in Tolmin (PPC) and RDA Rod in Ajdovščina. RDAs (especially Northern Primorska RDA) are focused on promotion, education and co-ordination: they set-up various tenders for entrepreneurs, organize business and educational events, setup e-database for firms, prepare and lead projects. Occasionally they provide business plans as they have a licence for business consultants. They suggest that entrepreneurs in the Goriška region mostly "do not feel the need for education" (Mihelj, 2011) although they have participated in courses on taxes, book-keeping, sanitary standards etc. 


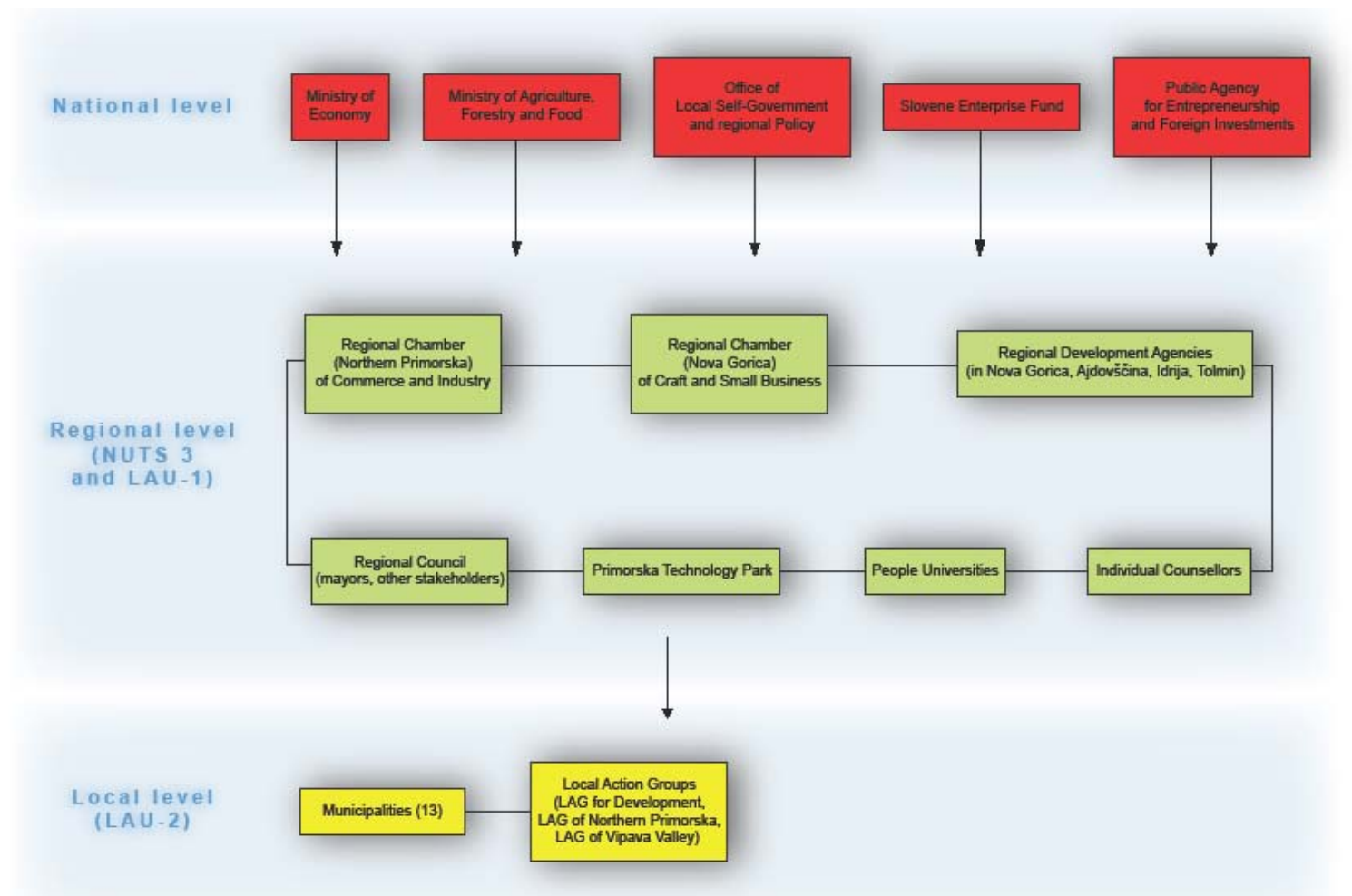

Fig 6. Scheme of business-support institutions in the Goriška region. Source: DERREG, Brokering Network Interviews, 2011.

- There are usually small (financially and from the personnel point of view) economic departments (at the urban municipality of Nova Gorica)/experts at municipalities (usually in smaller municipalities): small municipalities offer modest financial means to firms. Those municipalities that are financially stronger open more calls for SMEs. There has been some over-lapping in this field, since the municipalities are also founders and co-financers of the RDAs mentioned (Mihelj, 2011).

- Primorska Technology Park works as a business incubator, aiming to strength co-operation with the University of Nova Gorica and is focused on entrepreneurship development and international projects.

Before the recession there were more than 10 individual entrepreneurship consultants, now there are less than 5.

An important role for setting business priorities in the region is recognized by the Regional Council that links mayors and various regional stakeholders.

- Public people universities has an important role for business mentality development as they provide programmes for vocational education and attract different social groups.

- At local level, LEADER initiatives have introduced the idea of local action groups (LAGs): three of them are active in the Goriška region having had their strategy confirmed by the Ministry of Agriculture, Forestry and Food. Following the Rural Development Programme 2007-2013 they have been applying for project financing.

\subsection{The Case of Business Zones in Godovič}

The location of BZ in Godovič dates back to the late 1970s with the implementation of polycentric regional development established by the local municipality's act. Nowadays the BZ extends over 32,2 ha (big in Slovenian terms, with possible enlargement, but with private land ownership) and hosts 5 firms with nearly 600 employees. The largest firm (500 employees) specializes in the production and research of complex air-heating systems, photovoltaic and solar system. Other firms are SMEs and are involved in transport and logistics. There are two sawmills and one metal manufacturing enterprise. 
It is important that the $B Z$ is located in a rural environment, at the same time separated, but next to the settlement of Godovič, with relatively good accessibility via the national highway system (35 minutes drive by car from the national capital). The employees commute daily from an area of $30 \mathrm{~km}$ radius approximately with the local road connections deemed a problem by many entrepreneurs.

The BZ was essentially up-graded in 2006 when the largest firm set-up the first research institute in Slovenian rural area. This works as a pull factor for local highly qualified workers (mostly engineers with $\mathrm{PhDs}$ ), and also attracts daily local/regional in-migration.

Interviewee SI17: "The company is important not just locally, but also in the regional sense regarding employment: besides production the firm (they also have production units in Germany and Bosnia) is focused on research. As a consequence, the professional knowledge and hightech skills are pull factors for broader high qualified labour market "

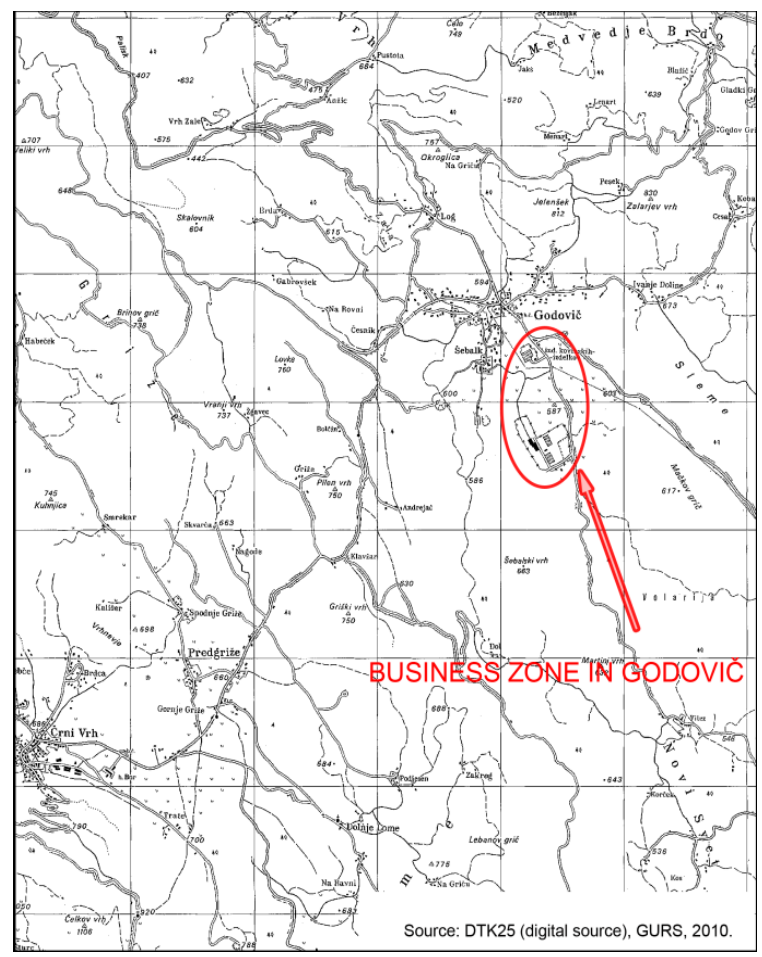

Fig 7. The Location of BZ Godovič.

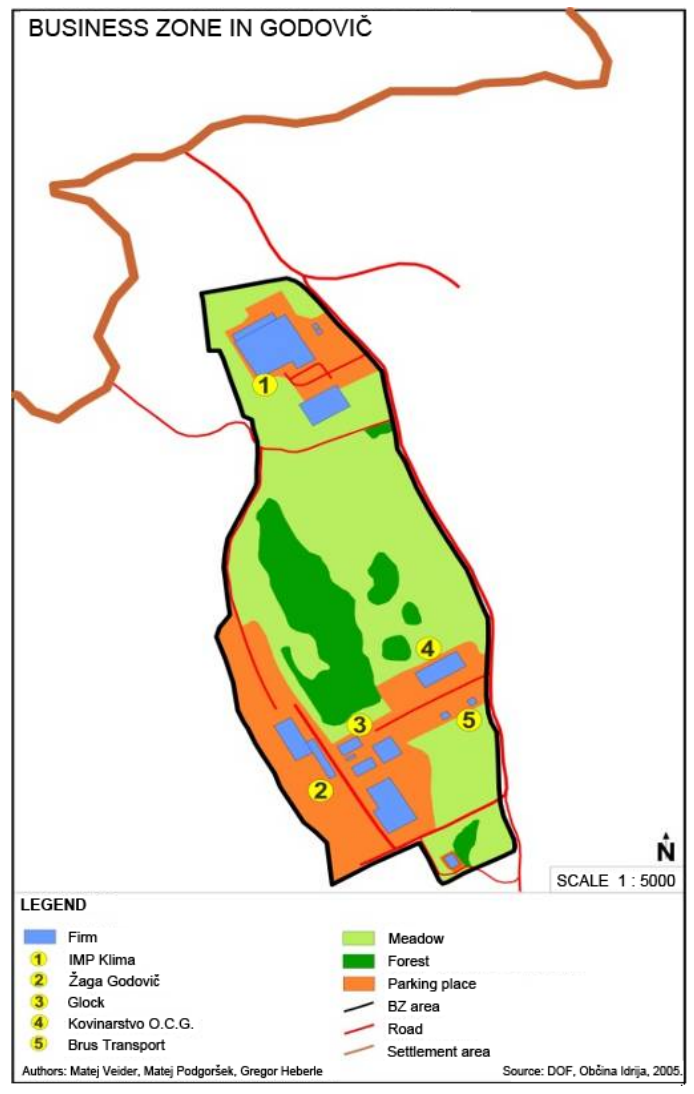

Fig 8. The Outline of BZ Godovič.

The built-up environment is well developed with high natural amenities of the area attracting middle and upper management to move their permanent residence in the area. The local population is proud of this $\mathrm{BZ}$, but the environmental over-burdening (noise, dust) due to two sawmills is problematic.

\section{Conclusion and Discussion}

This paper has focused on the interesting multilayered and multifaceted interrelationships that firms in rural areas establish with their local and international environment in this era of globalization. The research formed an integrative part of an international research project (DERREG 2009-2011) that elected the Goriška region as a case study area. The area is very heterogeneous in geographical structure, forms part of vital transborder region, embodies huge diversity of historical, cultural and natural heritage and has specific and less favourable conditions for agriculture with significant inter-regional disparities.

Small scale research, combining quantitative and qualitative methods to test our initial hypothesis, was conducted. In terms of outcomes, it is not obviously evident that more locally 
oriented firms (in terms of sales, purchase, business co-operation, financing etc.) are more embedded to local environments; nor can it be completely confirmed that strongly internationalized (globalized) firms in rural areas tend to be less embedded in local milieu. To interrogate further, we surveyed two drivers that essentially create local/regional/international business environments, i.e. the development of built-up facilities and the forms of a supportive business climate. Both mentioned drivers when set-up and correlating properly, should create favourable circumstances in which firms could flourish and network on various levels.

In the Goriška region, 20 SMEs (including one large firm) replied to the email questionnaire. Despite dispersed distribution regarding the geographical location, firm age and sector of activity, the sample cannot be observed as representative of all SMEs located in the western part of Slovenia. However, the responses gathered enable us to provide valuable insight into how SMEs located in such territorial setting are able to develop and maintain certain structures of their business networks.

The majority of surveyed firms in the Goriška region are highly integrated into international and globalized market as a consequence of relatively small domestic market and long-lasting crossborder relations. The majority of firms, especially in this border zone to Italy, have resilience strategies adopted for 20-30 years - as they are mostly export oriented (European networks prevail). Some firms however are more strongly embedded in local and regional environments. Some traditional firms (dairy, grapevine growing) are locally embedded in the field of supply (fresh high quality milk, reeds etc.) and have developed different resilience strategies. For the majority of firms, the suppliers usually come from local and regional environs; the exception being firms with foreign owners or those with extremely specialised production (e.g. acrilate teeth).

Although companies are acting in a local milieu (mostly they are located in the business zone which provides them, more or less, with a suitable built-up business environment) they need to adopt the most modern approaches if they want to survive. Firms (it does not matter whether they are localised or internationalized by the OECD definition) are usually strongly connected to local environments (with some evident exceptions). Although the business supportive milieu is quite dispersed by its nature, the surveyed firms use their facilities and services differently: more globalised firms use them usually within market positioning; some localized firms use public funding and services. Key support actors include trade organizations and public agencies, with national research institutes and business consultants also playing an important role for some enterprises. This indicates the significance of regional structures and institutions in supporting rural business in developing international opportunities.

Local embeddedness increases resilience and the return of benefits to the region from global engagement. Firms trading internationally should be encouraged to source materials locally, and to participate in regional support networks (DERREG, European Policy Briefing 2011). Networking inside rural areas (a rural web connecting tangible and intangible capital) combined with purpose and long-term international networking is necessary nowadays for the success of local/rural economies.

\section{Acknowledgement}

*DERREG project (Developing Europe's Rural Areas in the Era of Globalization; for details visit www.derreg.eu) is an international research project, financed under $7^{\text {th }}$ Framework Programme of the EU DG Research. Department of Geography (Faculty of Arts, University of Ljubljana) is a partner of DERREG international research team. Since January 2009 we have been developing a methodology on assessing the impacts of globalization on rural areas (here the perspective of small business development is to be highlighted) and testing it in several EU countries. 
[1] AJPES: Agency of the Republic of Slovenia for Public Legal Records and Related Services (2008, 2009). http://www.ajpes.si/

[2] Blakely, E. J. \& Bradshaw, T. K. (2002). Planning Local Economic Development. Theory and Practice. Thousand Oaks: Sage Publications.

[3] DERREG (2009-2011). Report on conceptual, methodological aspects, data collection strategy and first empirical results (p. 14, 43). E-survey, In-depth interviews, Network brokering interviews, European Policy Briefing 2011.

[4] Dubois, A. (2010). Firms in Networks: The Case of SMEs in Peripheral, Sparsely Populated Regions of Sweden. Paper presented at the 2010 Conference of the Regional Studies Association, Regional responses to global shifts, 5-8.

[5] Epp, R. \& Whitson, D. (2001). Writing off the Rural West: Globalization, Governments, and the Transformation of Rural Communities. Edmonton: University of Alberta.

[6] Granovetter, M. (1985). Economic action and social structure: a theory of embeddedness. American Journal of Sociology 91(3), 481-510.

[7] Granovetter, M. (1992). Problems of explanation in economic sociology. In Nohria, N. \& Eccles, R. (eds), Networks and Organizations: Structure, Form and Action. Boston: Harvard Business School Press.

[8] Hogan, J. (2004). Constructing the global in two rural communities in Australia and Japan. Journal of Sociology 40(1), 21-40. Doi: 10.1177/1440783304040451.

[9] Johannisson, B., Ramirez-Pasillas, M. \& Karlsson, G. (2002). The institutional embeddedness of local inter-firm networks: a leverage for business creation. Entrepreneurship and Regional Development. 14(4), 297-315.

Doi: 10.1080/08985620210142020.

[10] Klemenčič, M. M., Lampič, B., Potočnik Slavič, I. (2008). Življenjska (ne)moč obrobnih podeželskih območij v Sloveniji. GeograFF, 3. Ljubljana.

[11] Klemenčič, M. M. (2005). Nova razvojna strategija pokrajinsko homogenih obrobnih območij Slovenije. Dela 24, 185-193.

[12] Massey, D. (2005). For Space. London: Sage.

[13] Mihelj, B. (2011). Business supportive environment, RDA Northern Primorska (oral source, January 2011).

[14] National Development Programme of the RS 2007-2013 (2008). Ljubljana.

[15] National Strategic Reference Framework (2008). Ljubljana.

[16] Operational Programe of Environmental and Transport Infrastructure Development (2008). Ljubljana.

[17] Ploeg van der, J. D. \& Marsden, T., eds. (2008). Unfolding Webs: The Dynamics of Regional Rural Development. Assen: Van Gorcum.

[18] Potočnik Slavič, I. (2010a). Geografski vidik obrtno-poslovnih con na slovenskem podeželju. Ljubljana: IB rev.

[19] Potočnik Slavič, I. (2010b). Endogeni razvojni potenciali slovenskega podeželja. GeograFF, 7. Ljubljana.

[20] Regionalni razvojni program Severne Primorske (Goriške statistične regije) 2007-2013 (2007). Kobarid.

[21] Resolution on National Development Projects for the period 2007-2023 (2008). Ljubljana. 
[22] Rural Development Programme 2007-2013 (2007). Ministrstvo za kmetijstvo, gozdarstvo in prehrano, Ljubljana.

[23] SURS: Statistical Bureau of the Republic of Slovenia (2002-2011). http://www.stat.si/

[24] Taylor, P.J. (2004). Regionality in the World City Network. International Social Science Journal 56(181), 361-372. Doi : 10.1111/j.0020-8701.2004.00499.x.

[25] Woods, M. (2007). Engaging the global countryside: globalization, hybridity and the reconstruction of rural place. Progress in Human Geography 31(4), 499-500. Doi: 10.1177/0309132507079503.

[26] Young, N. (2010). Business Networks, Collaboration and Embeddednedd in Local and Extra-local Spaces: The Case of Port Hardy, Canada. Sociologia Ruralis 50(4), 392-408. Doi: 10.1111/j.1467-9523.2010.00521.x. 